\title{
PERGESERAN BENTUK DAN FUNGSI RUMAH JOGLO DI WILAYAH BANYUWANGI
}

\author{
Rois Ainul Umah', Tian Fitriara Huda ${ }^{2}$ \\ Fakultas Keguruan dan Ilmu Pendidikan, Universitas PGRI Banyuwangi ${ }^{1}$ \\ Email: roisainul@gmail.com \\ Email: tianfitriarahuda@gmail.com
}

\begin{abstract}
Banyuwangi adalah sebuah wilayah yang kaya akan berbagai macam budaya dan adat istiadatnya, hal ini dikarenakan kecamatan Banyuwangi dihuni oleh berbagai suku bangsa. Penduduk mayoritas kecamatan Banyuwangi adalah suku osing yang banyak tinggal di kelurahan pakis dan kelurahan sumber rejo. Bangunan Joglo sebagai salah satu bangunan tradisional Jawa di dalamnya terkandung filosofi yang sesuai dengan kehidupan masyarakatnya. Susunan ruangan pada Joglo umumnya dibagi menjadi tiga bagian yaitu ruangan pertemuan yang disebut pendopo, ruang tengah atau ruang yang dipakai untuk mengadakan pertunjukan disebut pringgitan, dan ruang belakang yang disebut dalem atau omah jero sebagai ruang keluarga. Bagi masyakat Banyuwangi khususnya yang masih melestarikan rumah joglo sperti suku osing sudah mulai mengalami pergeseran peran dan fungsinya dimana dalam hal ini rumah joglo dijadikan sebagai keperluan tambahan penghias rumah, hunian pribadi warga, hinggaa digunakan sebagai bangunan permanen kafe dan restoran. Dari uraian diatas,peneliti merasa bahwa masyarakat kurang memahami akan fungsi peran dan bentuk arsitektur rumah jawa yang sudah menjadi budaya warisan perlahan berubah denganmenyebabkan pergeseran terhadap nilai kebudayaan yang terkandung dalam didalamnya. Pergeseran nilai tersebut cepat atau lambat akan membawa perubahan-perubahan terhadap bentuk, struktur dan fungsi arsitektur tradisional.
\end{abstract}

\section{Keywords :Pergeseran, bentuk dan fungsi, rumah joglo, Banyuwangi}

\begin{abstract}
Banyuwangi is an area rich in various cultures and customs, this is because Banyuwangi district is inhabited by various ethnic groups. The majority of the sub-districts of Banyuwangi are osing tribe who live in the village of fern and urban village of rejo. Joglo building as one of the traditional Javanese buildings in it contained philosophy that suits the life of the people. The arrangement of the room in Joglo is generally divided into three parts, namely the meeting room called pendopo, the living room or the space used to hold the show called pringgitan, and the back room called dalem or omah jero as the family room. For the people of Banyuwangi especially those who still preserve the joglo house just like the osing tribe have begun to experience the shifting of its role and function where in this case joglo house serve as additional need for home decoration, private residence of the citizen, until used as permanent building of
\end{abstract}


cafe and restaurant. From the description above, the researcher felt that the community did not understand the function of the role and shape of the architecture of the Javanese house which has become the culture of the inheritance slowly changed by causing a shift to the cultural values contained within it. The shift in value will sooner or later bring changes to traditional architectural forms, structures and functions.

Keywords: Shift, shape and function, joglo house, Banyuwangi

\section{Pendahuluan}

Banyuwangi adalah sebuah wilayah yang kaya akan berbagai macam budaya dan adat istiadatnya, hal ini dikarenakan kecamatan Banyuwangi dihuni oleh berbagai suku bangsa. Penduduk mayoritas kecamatan Banyuwangi adalah suku osing yang banyak tinggal di kelurahan pakis dan kelurahan sumber rejo. Di kelurahan lain juga terdapat suku osing namun jumlahnya tidak terlalu dominan dan telah berbaur dengan para pendatang dari luar Banyuwangi. Bangunan Joglo sebagai salah satu bangunan tradisional Jawa di dalamnya terkandung filosofi yang sesuai dengan kehidupan masyarakatnya. Susunan ruangan pada Joglo umumnya dibagi menjadi tiga bagian yaitu ruangan pertemuan yang disebut pendopo, ruang tengah atau ruang yang dipakai untuk mengadakan pertunjukan disebut pringgitan, dan ruang belakang yang disebut dalem atau omah jero sebagai ruang keluarga. Dalam ruang ini terdapat tiga buah senthong (kamar) yaitu senthong kiri, senthong tengah dan senthong kanan. Pendopo sebagai ruang terbuka berfungsi untuk menerima tamu.Struktur bangunan pada pendopo menggunakan umpak sebagai alas soko, 4 buah soko guru (tiang utama). Menurut kepercayaan jawa, tingkatantingkatan ini akan menyatu pada satu titik. Ndalem ini adalah pusat susunan ruangruang di sekitarnya. Fungsi utamanya adalah sebagai ruang keluarga. Sifat ruangan ini pribadi, suasana yang ada di dalamnya tenang.

Kata budaya dalam bahasa Inggris disebut 'culture' yang artinya relatif rumit dan banyak teori, kosep dan definisi.Taylor, mendefinisikan: "budaya" sebagai keseluruhan kompleks, yang didalamnya termasuk ilmu pengetahuan, kepercayaan, seni, moral, hukum, tradisi dan semua kemampuan yang dibutuhkan manusia. Budaya memiliki makna sebagai cara hidup masyarakat yang selalu berkembang serta dimiliki oleh suatu kelompok manusia yang 
akan terus diturunkan atau diwariskan dari satu generasi ke generasi berikutnya. Budaya mencakup berbagai komponen di dalam struktur masyarakat seperti adat istiadat, bahasa, pakaian, rumah adat, masakan dan lain sebagainya. Budaya memiliki banyak unsur yang rumit, unik dan khas di dalamnya sehingga membedakan satu budaya dengan budaya lainnya.

Budaya adalah sesuatu yang diturunkan secara genetis dari satu generasi ke generasi berikutnya. Budaya juga merupakan sesuatu yang dapat dipelajari, terbukti dengan banyaknya siswa pertukaran budaya, tugas mereka adalah mempelajari budaya dari bangsa lain untuk dibawa ke negara asal mereka. Rumah traditional jawa sendiri merupakan salah satu bangunan arsitektur di Jawa. Rumah joglo mempunyai kerangka bangunan utama yang terdiri dari soko guru berupa empat tiang utama penyangga struktur bangunan serta tumpang sari yang berupa susunan balok yang disangga oleh soko guru. Susunan ruangan pada Joglo umumnya dibagi menjadi tiga bagian yaitu ruangan pertemuan yang disebut pendapa, ruang tengah yang disebut ruang pringgitan, dan ruang belakang yang disebut dalem yang berfungsi sebagai ruang keluarga.
Pada masyarakat suku Jawa rumah mempunyai peran yang sangat besar dalam melindunngi keluarga/orang yang tinggal di dalamnya. Hal pertama yang menyatakan itu adalah adanya pepatah Jawa yang mengatakan "mangan ora mangan pokoke kumpul" yang artinya makan atau tidak yang penting berkumpul bersama anggota keluarga lainnya.Keadaan ini sebetulnya hanya akan menunjukkan bahwa dalam keluarga Jawa kebersamaan dengan keluarga besar mempunyai arti yang sangat penting bagi kehidupannya. Suseno (1983 : 38-69)

Bagi masyakat Banyuwangi khususnya yang masih melestarikan rumah joglo sperti suku osing sudah mulai mengalami pergeseran peran dan fungsinya dimana dalam hal ini rumah joglo dijadikan sebagai keperluan tambahan penghias rumah, hunian pribadi warga, hinggaa digunakan sebagai bangunan permanen kafe dan restoran. Dari uraian diatas,peneliti merasa bahwa masyarakat kurang memahami akan fungsi peran dan bentuk arsitektur rumah jawa yang sudah menjadi budaya warisan perlahan berubah denganmenyebabkan pergeseran terhadap nilai kebudayaan yang terkandung dalam didalamnya. Pergeseran nilai tersebut cepat atau lambat akan 
membawa perubahan-perubahan terhadap bentuk, struktur dan fungsi arsitektur tradisional. Maka peneliti mengambil tema dengan judul "PERGESERAN BENTUK DAN FUNGSI RUMAH JOGLO DI WILAYAH BANYUWANGI"

\section{Kajian Literatur dan pengembangan Hipotesis}

\section{Pengertian Rumah}

Rumah dalam arti fisik merupakan tempat sebagian besar kegiatan dilakukan,. Rumah mengalami perubahan akibat meningkatnya pengetahuan manusia dari yang sederhana ke tingkat yang lebih kompleks. Pandangan mengenai konsep kemapanan dalam bertempat tinggal memberikan gambaran keberadaan dan status seseorang, yang memungkinkannya memiliki kontrol territorial terhadap ruang spasialnya. Rumah hanya salah satu cara yang nyata untuk mewujudkan upaya menghuni suatu tempat, yang terdiri dari struktur bangunan fisik yang memuat satuan simbolis, sosial dan praktis (Revianto, 2003).

Menurut Siswono Yudohusodo (1991: 432), rumah adalah bangunan yang berfungsi sebagai tempat tinggal atau hunian dan sarana pembinaan keluarga juga tempat awal pengembangan kehidupan. adapun pendapat lainnya seperti yang dikemukakan oleh Kimpraswil (2002:01) Rumah merupakan salah satu kebutuhan utama manusia, sehingga perencanaan pembangunan rumah harus cermat dan mempertimbangkan banyak hal. Beberapa diantaranya, yaitu potensi fisik dan potensi sosial budaya. Potensi fisik adalah pertimbangan akan bahan bangunan, kondisi geologis dan iklim setempat. Sedangkan, potensi sosial budaya terdiri atas arsitektur lokal dan cara hidup.

Adapun jurnal penelitian lain yang membahas tentang topik serupa, seperti yang dikemukakan oleh Sarwo (dalam Budihardjo, 1998:148)yang menyatakan bahwa Rumah merupakan suatu bangunan, tempat manusia tinggal dan melangsungkan kehidupannya. Di samping itu, rumah juga merupakan tempat berlangsungnya proses sosialisasi pada saat seorang individu diperkenalkan kepada norma dan adat kebiasaan yang berlaku di dalam suatu masyarakat. Dari pengertian diatas dapat disimpulkan bahwa rumah merupakan salah satu kebutuhan manusia yang berupa tempat tinggal berlangsungnya proses sosialisasi di dalam masyarakat.Dalam Perencanaan 
pembangunan rumah memiliki beberapa potensi yaitu potensi fisik dan potensi social budaya. Rumah merupakan salah satu cara yang nyata untuk mewujudkan upaya menghuni suatu tempat, yang terdiri dari struktur bangunan fisik yang memuat satuan simbolis, sosial dan praktis.

\section{Rumah Joglo}

Rumah joglo merupakan jenis bangunan bangunan tradisional yang terkenal di daerah jawa.Menurut Frick, (1997: 218)Rumah joglo merupakan gaya bangunan rumah tradisional Jawa. Bentuk atapnya menyerupai gunungan dengan mala yang sangat pendek, disertai lambang tumpang sari. Rumah joglo juga disebut rumah tikelan (patah) karena atap rumah seolah-olah patah menjadi tiga bagian yaitu: brunjung, penanggap dan panitih.

Selain itu pendapat lain dikemukakan oleh Sastroatmojo, (2006:39) yang menyatakan bahwa Rumah joglo dalam pemahaman Jawa merupakan cerminan sikap, wawasan serta tingkat ekonomi-sosio-kultural masyarakatnya. Rumah dengan demikian tidak ubahnya adalah gaya hidup seseorang. Menurut Azkadia Aqtami (2013:01) Rumah joglo merupakan salah satu arsitektur khas Indonesia yang berasal dari daerah Jawa. Karakteristik rumah joglo yaitu terletak kerangka bangunan utama yang terdiri dari soko guru berupa empat tiang utama penyangga struktur bangunan serta tumpang sari yang berupa susunan balok yang disangga oleh soko guru. Susunan ruangan pada Joglo umumnya dibagi menjadi tiga bagian yaitu ruangan pertemuan yang disebut pendapa, ruang tengah yang disebut ruang pringgitan, dan ruang belakang yang disebut dalem yang berfungsi sebagai ruang keluarga.

Ada pun jurnal penelitian lain yang membahas tentang rumah joglo salah satunya adalah (Santosa, 2000:68) dalam jurnal penelitian Nilai Kearifan Lokal Rumah Tradisional Jawa. Dalam isi penelitian tersebut santoso mengemukakan bahwa rumah tradisional Jawa yaitu rumah joglo bukan sekedar tempatuntuk berteduh (fungsi praktis),melainkan juga dimaknai sebagai bentuk perwujudan dari cita-cita dan pandangan hidupnya atau fungsi simbolis. Jadi dapat disimpulkan bahwa rumah joglo merupakan rumah tradisional jawa yang mempunyai karakteristik bangunan dengan desain arsitektur yang cukup unik. Salah 
satu keunikan tersebut terletak pada desain rangka atapnya yang memiliki bubungan cukup tinggi. Desain atap yang demikian dihasilkan dari pola tiang-tiang yang menyangga rumah.

\section{Metode Penelitian}

Menurut Rosady Ruslan (2008: 24), metode adalah kegiatan ilmiah yang berkaitan dengan suatu cara kerja (sistematis) untuk memahami suatu subjek atau objek penelitian, sebagai upaya untuk menemukan jawaban yang dapat dipertanggung jawabkan secara ilmiah dan termasuk keabsahannya.Selanjutnya, menurut Menurut Sugiyono (2005 : 01), metode penelitian pada dasarnya merupakan cara ilmiah untuk mendapatkan data dengan tujuan dan kegunaan tertentu.

Dari kedua pendapat tersebut dapat disimpulkan bahwa metode penelitian adalah suatu cara yang digunakan dalam mengumpulkan data,secara teratur dan sistematis untuk mencapai tujuan yang dapat dipertanggung jawabkan. Selanjutnya, dalam memecahkan suatu masalah yang ada pada saat penelitian serta untuk mencapai tujuan penelitian, tidak akan terlalu sulit untuk dipecahkan. Maka penulis menggunakan metode deskriptif yaitu, metode yang didasarkan pada data yang ada pada masa sekarang atau penyelidikan yang bertujuan pada pemecahan masalah yang ada pada masa sekarang. Metode deskriftif merupakan metode yang didasarkan pada data yang ada pada masa sekarang atau penyelidikan yang bertujuan pada pemecahan masalah yang ada pada masa sekarang.Menurut Sukmadinata (2006:72) metode deskriptif adalah suatu bentuk penelitian yang ditujukan untuk mendeskripsikan fenomena-fenomena yang ada, baik fenomena alamiah maupun fenomena buatan manusia. Fenomena itu bisa berupa bentuk, aktivitas, karakteristik, perubahan, hubungan, kesamaan, dan perbedaan antara fenomena yang satu dengan fenomena lainnya. Jadi penelitian ini bermaksud untuk mengetahui perkembangan yang disebabkan pengaruh modernisasi, dengan metode ini penulis menggunakan deskriptif untuk menggambarkan perubahan-perubahan terhadap bentuk, struktur dan fungsi arsitektur tradisional yaitu pergeseran bentuk dan fungsi rumah joglo di wilayah banyuwangi. 


\section{Refrensi}

BAHASA DAN SENI. Tahun 39. Nomor 1, Februari 2011 September 2006.

Balai Pustaka. Van Peursen. 1989. Strategi Kebudayaan. Kanisius.

Burhan Bungi. 2003. Analisa Data Penelitian Kualitatif Pemahaman

Filosofis dan Metodologis Kearah Penguasaan Modal Aplikasi. Jakarta: PT. Raja Grafindo Persada

Lexy J. Moleong. 199. Metodologi

Penelitian Kualitatif. Bandung:

Remaja Rosda Karya.

Moh.Nazir. Ph. D. 2003. Metode Penelitian. Jakarta: PT. Ghalia Indonesia

Sastroatmojo, S. 2006. Citra diri orang Jawa.Yogyakarta: Narasi

Siswono Yudohusodo . 1991. Rumah Untuk Seluruh Rakyat.

Koentjoroningrat. 1984. Kebudayaan Jawa. Jakarta.

Pasaribu.Roland B.F. Budaya dan Masyarakat (jurnal)

Revianto. 2000. Omah: Membaca Makna Rumah Jawa. Yayasan Benteng Budaya. Yogyakarta. 200:3

Sukardi, Metodologi Penelitian Pendidikan, Yogyakarta: Bumi Aksara, 2003

Simatupang, L.L. 2006. "Jagad Seni: Refleksi Kemanusiaan" Makalah disampaikan dalam Workshop Tradisi Lisan Sebagai Wahana Komunikasi yang Sangat Efektif di Tengah Masyarakat yang Sedang Berubah tanggal 6 \begin{tabular}{ll|l} 
& 78 & Yogyakarta: Balai
\end{tabular} Kajian Sejarah dan Nilai Tradisional.

Sugiyono.2013. Metode Penelitian Kuantitatif, Kualitatif DanR\&D. Alfabeta : CV Bandung

Suharsaputra, Uhar. 2014. Metode

Penelitian Kuantitatif, Kualitatif dan

Tindakan. Bandung: PT. Refika

Aditama.
Suseno, Franz Magnis. 1988 "Etika Jawa": Sebuah Analisa Falsafi Tentang Kebijaksanaan Hidup Jawa, Jakarta: PT. Gramedia. 